\title{
Seasonal nekton assemblages in a flooded coastal freshwater marsh, Southwest Louisiana, USA
}

\author{
Sung-Ryong Kang ${ }^{1^{*}}$, Sammy L. King ${ }^{2}$ \\ ${ }^{1}$ School of Renewable Natural Resources, Louisiana State University Agricultural Center, Baton Rouge, USA; \\ ${ }^{*}$ Corresponding Author: skang562@gmail.com \\ ${ }^{2}$ U.S. Geological Survey, Louisiana Cooperative Fish and Wildlife Research Unit, School of Renewable Natural Resources, Louisi- \\ ana State University Agricultural Center, Baton Rouge, USA
}

Received 27 February 2013; revised 30 March 2013; accepted 24 April 2013

Copyright (C) 2013 Sung-Ryong Kang, Sammy L. King. This is an open access article distributed under the Creative Commons Attribution License, which permits unrestricted use, distribution, and reproduction in any medium, provided the original work is properly cited.

\section{ABSTRACT}

Marsh flooding and drying may be key factors affecting seasonal nekton distribution and density because habitat connectivity and water depth can impact nekton accessibility to the marsh surface. Recent studies have characterized freshwater nekton assemblages in marsh ponds; however, a paucity of information exists on the nekton assemblages in freshwater emergent marshes. The principal objectives of this study are to characterize the seasonal nekton assemblage in a freshwater emergent marsh and compare nekton species composition, density, and biomass to that of freshwater marsh ponds. We hypothesize that 1) freshwater emergent marsh has lower taxa richness than freshwater marsh ponds; and 2) freshwater emergent marsh has a lower seasonal density and biomass than freshwater marsh ponds. Mosquitofish Gambusia affinis and least killifish Heterandria formosa were abundant species in both habitats while some abundant species (e.g., banded pygmy sunfish Elassoma zonatum) in freshwater ponds were absent in freshwater emergent marsh. Our data did not support our first and second hypotheses because taxa richness, seasonal density and biomass between freshwater emergent marsh and ponds did not statistically differ. However, freshwater emergent marsh was dry during the summer months and thus supports no fish species during this period. Additional long-term research on the effects of flow regime in the freshwater marsh on nekton assemblages would potentially improve our understanding of nekton habitat requirements.

Keywords: Freshwater Emergent Marsh; Freshwater Pond; Nekton Assemblage; Hydrologic Connection

\section{INTRODUCTION}

Regional-scale patterns in the distribution of organisms result primarily from species responses to their physical environment because dominant abiotic variables are thought to act like a physiological sieve [1,2]. Marsh flooding and drying are likely to be key factors affecting seasonal nekton distribution and density because habitat connectivity and water depth can determine nekton accessibility to the marsh surface [3-7]. Moreover, flow regime plays a profound role in the lives of fish through its effect on critical life events (e.g., reproduction, spawning, larval survival, recruitment) [8-13]. In this sense, lateral hydrologic connectivity between coastal freshwater emergent-herbaceous marsh (adjacent to ponds and channels; hereafter termed "freshwater emergent marsh, FEM") and ponds during flooding may increase nekton density in the freshwater emergent marsh while nekton density in ponds may decrease due to nekton movement from ponds to the freshwater emergent marsh. However, shallow water depths may not provide equal access for all nekton (e.g., larger species) thereby restricting some nekton taxa from the freshwater ponds. Also, ponds that have a relatively longer hydroperiod and longer hydrologic connectivity to permanent water bodies may have relatively higher nekton density and biomass than the freshwater emergent marsh. For example, several studies suggest that a low degree of connection with adjacent waterways support relatively few organisms due to limited recruitment [14] and severe envi- 
ronmental conditions (e.g., salinization, drying [15-17]).

In freshwater habitats, low dissolved oxygen (DO) also creates stressful conditions for many species [18]. However, relatively abundant species (e.g., mosquitofish) in freshwater marsh are adapted to low DO. [19] documented that mosquitofish reached the greatest abundance in habitats with relatively low DO (e.g., $2 \mathrm{mg} / \mathrm{L}$ ), high submerged aquatic vegetation (SAV) cover, and low salinity (e.g., <0.5 ppt). Thus, nekton assemblages in freshwater emergent marshes and ponds may have similar dominant species even though freshwater emergent marshes exhibit severe environmental conditions (e.g., drying).

The extent of coastal marsh loss in many parts of the world has intensified efforts to develop marsh management and conservation strategies that include habitat value assessment for nekton [20-23]. [24] characterized freshwater nekton assemblages in marsh ponds, however, a paucity of information exists on nekton assemblages in freshwater emergent marshes compared to assemblages in freshwater marsh ponds. A clear understanding of the similarity and differences between freshwater emergent marsh and marsh ponds would enhance our understanding of nekton habitat requirements in freshwater marshes as well as the effects of anthropogenic activities, such as habitat conversion (e.g., freshwater emergent marsh to pond), on their distribution. The principal objectives of this study are to characterize the seasonal nekton assemblage in a freshwater emergent marsh and compare nekton species composition, density, and biomass to that of freshwater marsh ponds. We hypothesize that 1) freshwater emergent marsh has lower taxa richness than marsh ponds; and 2) freshwater emergent marsh has a lower seasonal density and biomass than marsh ponds.

\section{STUDY AREA AND METHODS}

\subsection{Study Area}

This study was conducted in White Lake Wetlands Conservation Area (WLWCA, 29 $52^{\prime} \mathrm{N}, 92^{\circ} 31^{\prime} \mathrm{W}$, Figure 1) in the Chenier Plain of southwestern Louisiana. WLWCA, a 28,719 ha freshwater marsh, is bounded on the south by White Lake $(28.2 \mathrm{~km}$ north of the Gulf of Mexico). Dominant vegetation is maidencane (Panicum hemitomon Schultes) and bulltongue arrowhead (Sagittaria lancifolia Linnaeus). We used marsh vegetation (i.e., freshwater marsh: Panicum hemitomon, [25]) to define our marsh types because vegetation does not respond to daily salinity fluctuations $[25,26]$. Salinity (i.e., freshwater marsh: 0.1 - $3.4 \mathrm{ppt}$ ) was also a major consideration of our decision to select marsh types.

\subsection{Data Collection}

In November 2008, we deployed continuous water

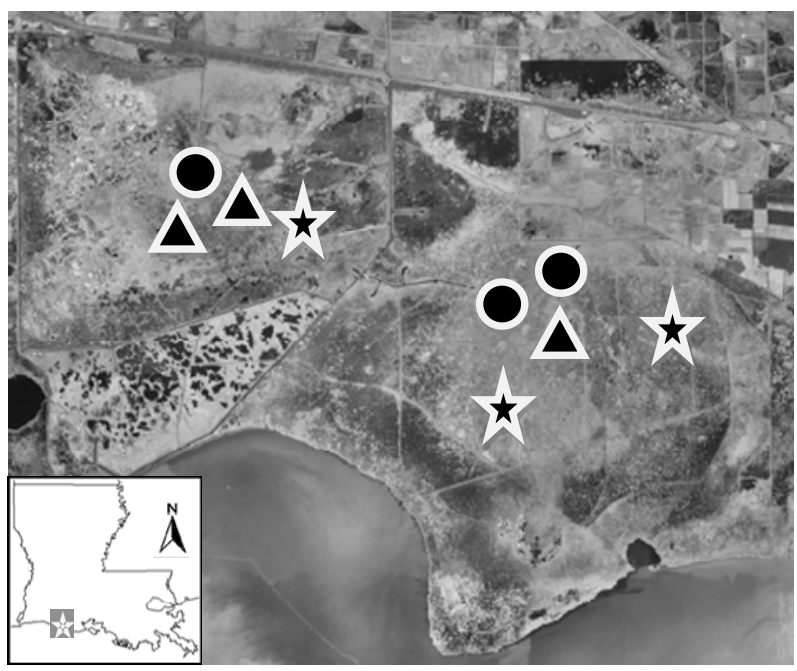

Figure 1. White lake wetlands conservation area is located in the Chenier plain of southwestern Louisiana. Stars (FEMs), triangles (PCPs), and circles (TCPs) are our sampling points in the marshes.

level recorders in freshwater emergent marshes (i.e., 100 $\mathrm{m}$ from channel or pond margin) and ponds to measure water depth 6 times per day. Water depths were validated by comparing water level recorder readings to discrete monthly water depths obtained with a meter stick adjacent to the recorder; both water depths were always within $1 \mathrm{~cm}$ of each other. We then determined flooding depth and duration based on the criteria that daily water depth $($ DWD $)>0$. We also deployed a staff gage at the border between the pond and freshwater emergent marsh to measure disconnection of surface water and connected water depth (CWD). CWD was the water depth at the border between the pond and the freshwater emergent marsh when the pond is connected with surface water to the channel or surrounding marsh (marginal zone of the pond).

To determine nekton characteristics, we sampled freshwater emergent marshes (i.e., $100 \mathrm{~m}$ from channel or pond margin) seasonally from March 2009 to February 2010. Seasons were defined as: 1) Spring (MarchMay); 2) Summer (June-August); 3) Fall (SeptemberNovember); 4) Winter (December-February). A $1-\mathrm{m}^{2}$ aluminum-sided throw trap (mesh size: $3 \mathrm{~mm}$ ), similar to that described by [28], was tossed at three random points in each sampling plot within the freshwater emergent marsh (4 sampling sites) and ponds (i.e., 3 permanently connected ponds [PCP: permanently connected by a channel during all seasons], 3 temporarily connected ponds [TCP: temporarily connected by surface water to the surrounding marsh but not permanently connected to a channel], [24]). Sweeps with a $1 \mathrm{~m}$ wide bar seine (3 $\mathrm{mm}$ mesh size) were used to remove the nekton from the trap. Five consecutive sweeps without collecting organ- 
isms were completed before the trap was considered free of nekton. Fish and decapod crustaceans were frozen and returned to the laboratory where they were sorted and identified to species or to the lowest possible taxon. All nekton were weighed to the nearest $0.001 \mathrm{~g}$ wet-weight to determine biomass $\left(\mathrm{g} \cdot \mathrm{m}^{-2}\right)$.

\subsection{Statistical Analysis}

Data are reported as mean \pm standard error (SE), and significance level was chosen at $\alpha=0.05$. Analyses of variance (ANOVA) and T-test (Proc Mixed, Version 9.3, Cary, SAS Institute, North Carolina) were used to test for statistical differences in environmental variables and nekton density and biomass by season. We used one-way ANOVA for each response variable that included environmental variable and nekton density. We conducted a one-way ANOVA with one fixed effect. Significant oneway ANOVA effects were tested using post-hoc comparisons of Tukey adjusted least squared means. For ANOVA analyses, data were tested for normality with the Shapiro-Wilks test. In the event that the residuals were not normally distributed, the data were log-transformed. Linear regression (Proc Mixed, Version 9.3, SAS Institute, North Carolina) was used to examine the potential relationship between nekton assemblage characteristics (i.e., density, biomass) and environmental factors.

\section{RESULTS}

In the freshwater emergent marshes, summer was the driest period (flooded days: 23/92 days) and winter was the wettest period (flooded days: 90/90 days). DWD ranged from $31.7 \pm 0.54 \mathrm{~cm}$ (mean $\pm \mathrm{SE}$; winter) to $1.3 \pm$ $0.41 \mathrm{~cm}$ (summer). DWD differed among all seasons $\left(\mathrm{F}_{3,12}=190.55, p<0.01\right)$. CWD ranged from $40.2 \pm 2.14$ $\mathrm{cm}$ (winter, PCP) to $2.9 \pm 1.02 \mathrm{~cm}$ (summer, PCP).

We recorded 439 individuals of 11 taxa in 60 samples in the freshwater emergent marsh. Seasonal nekton density (organisms $/ \mathrm{m}^{2}$ ) ranged from $14.7 \pm 5.37$ (mean $\pm \mathrm{SE}$; winter) to 0 (summer, Figure 2). However, nekton density within freshwater emergent marsh did differ among spring, fall, and winter $\left(\mathrm{F}_{2,9}=0.52, p=0.61\right)$. Nekton biomass ( $\mathrm{g}$ wet $\mathrm{wt} / \mathrm{m}^{2}$ ) ranged from $4.9 \pm 0.95$ (winter) to 0 (summer). Nekton biomass had similar seasonal patterns as nekton density $\left(\mathrm{F}_{2,9}=2.47, p=0.14\right)$. No statistically significant relationships were observed between environmental variables and nekton density/biomass in the freshwater emergent marsh. Relatively abundant species were mosquitofish (spring: 58\%, fall: 29\%, winter: 23\%), least killifish (spring: 34\%, fall: 30\%, winter: 24\%), and swamp dwarf crawfish (spring: $7 \%$, fall: $30 \%$, winter: $34 \%$ ).

In the freshwater marsh ponds, we recorded 22 nekton

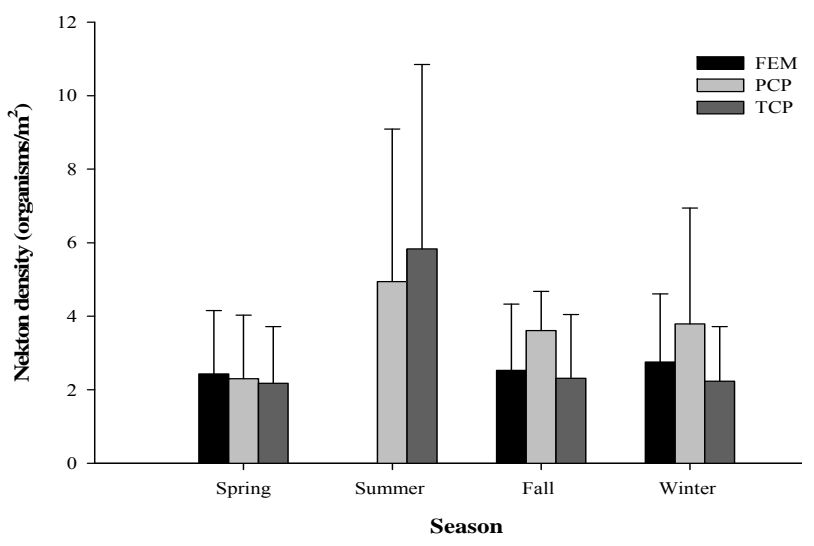

(a) Density

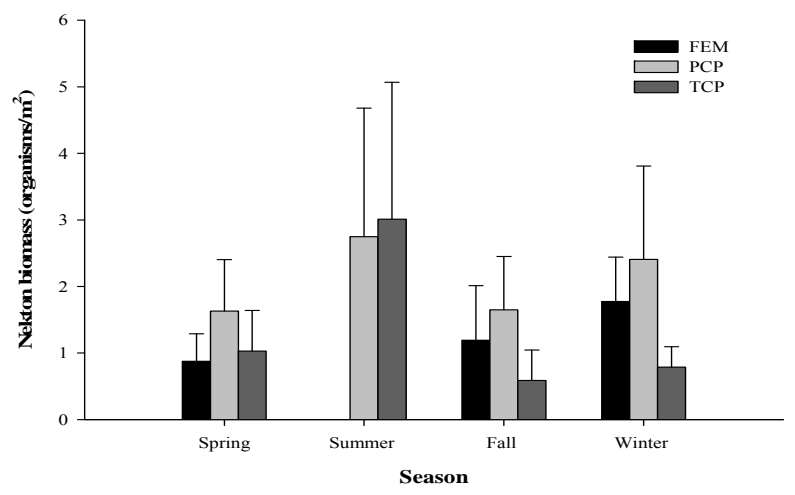

(b) Biomass

Figure 2. Seasonal nekton density $(\log (x+1)$ transformed organisms $/ \mathrm{m}^{2}( \pm \mathrm{SE}),(\mathrm{a})$ and biomass $(\log (\mathrm{x}+1)$ transformed $\mathrm{g}$ wet $\mathrm{wt} / \mathrm{m}^{2}$, (b) in throw trap samples by different habitat types in freshwater marsh from March 2009 to February 2010.

taxa in 90 samples. Nekton density and biomass between freshwater emergent marsh and ponds did not differ for any season (Table 1). A total of 22 taxa were found in ponds and 11 taxa in the freshwater emergent marsh; no unique species were observed in the freshwater emergent marsh. Freshwater emergent marsh and ponds shared some abundant species (i.e., mosquitofish, least killifish) but some abundant species (i.e., banded pygmy sunfish, golden topminnow Fundulus chrysotus) in freshwater ponds were absent in the freshwater emergent marsh.

\section{DISUSSION}

The present study considered the hypothesis that freshwater emergent marsh would have lower nekton taxa richness than freshwater marsh ponds due to seasonal isolation of surface water from other water bodies, such as ponds/channels, and relatively shallow CWD. As habitats become spatially reduced, the contact among species may intensify and/or harsh abiotic conditions may develop; in either case, some species may go locally extinct [29]. In addition, the relatively shallow flooded water depth $(<32 \mathrm{~cm})$ in freshwater emergent marsh may 
Table 1. Mean species nekton density $\left(\operatorname{organisms} / \mathrm{m}^{2}( \pm \mathrm{SE})\right)$ in throw trap samples by different habitat types in freshwater marsh from March 2009 to February 2010.

\begin{tabular}{|c|c|c|c|}
\hline & FEM & PCP & TCP \\
\hline Banded pygmy sunfish & & $4.1(1.84)$ & $1.0(0.57)$ \\
\hline Bantam sunfish & $0.1(0.06)$ & $1.5(0.49)$ & $0.0(0.03)$ \\
\hline Bayou killifish & & $0.1(0.06)$ & \\
\hline Bluegill & $0.1(0.06)$ & $0.7(0.63)$ & \\
\hline Creek chubsucker & & $0.0(0.03)$ & $0.1(0.06)$ \\
\hline Golden topminnow & $0.2(0.16)$ & $2.1(1.52)$ & $1.1(0.97)$ \\
\hline Grass pickerel & $0.0(0.04)$ & $0.1(0.11)$ & \\
\hline Grass shrimp & $0.0(0.04)$ & $9.5(4.65)$ & $1.6(0.54)$ \\
\hline Least killifish & $2.6(0.88)$ & $19.1(12.61)$ & $17.7(15.27)$ \\
\hline Mosquitofish & $3.2(1.23)$ & $12.8(9.82)$ & $69.5(65.66)$ \\
\hline $\begin{array}{l}\text { Northern starhead } \\
\text { topminnow }\end{array}$ & & $0.2(0.11)$ & $0.1(0.06)$ \\
\hline Pirate perch & & $0.0(0.00)$ & \\
\hline Rainwater killifish & $0.0(0.02)$ & $1.4(1.37)$ & \\
\hline Redspotted sunfish & & $0.2(0.07)$ & \\
\hline Red swamp crawfish & $0.2(0.20)$ & $0.1(0.06)$ & \\
\hline Sailfin molly & $0.4(0.30)$ & $2.9(2.80)$ & $0.3(0.24)$ \\
\hline Sheepshead minnow & & $0.6(0.57)$ & \\
\hline Spotted bass & & $0.1(0.06)$ & \\
\hline Swamp darter & & $0.0(0.03)$ & \\
\hline Swamp dwarf crawfish & $2.3(1.15)$ & $1.2(0.73)$ & $0.3(0.21)$ \\
\hline Warmouth & & $0.0(0.00)$ & \\
\hline Yellow bullhead & & $0.0(0.03)$ & \\
\hline
\end{tabular}

restrict accessibility of large predator species (e.g., bantam sunfish, bluegill). Our data did not support our first hypothesis as taxa richness between freshwater emergent marsh and ponds did not statistically differ, although no fish taxa used the emergent marsh in summer because of lack of water. Similarly, [27] noted that nekton taxa in intermediate marsh ponds included most of the nekton taxa in flooded intermediate freshwater emergent marsh (88\% same species). This finding suggests that nekton in freshwater emergent marsh is a nested subset of those in freshwater marsh ponds.

[24] noted that nekton density in freshwater marsh ponds was negatively correlated with CWD and this relationship appears to be related to flooding of the adjacent freshwater emergent marsh. When freshwater emergent marsh is flooded (i.e., lateral hydrologic connectivity), some nekton species will migrate from ponds to the marsh, resulting in decreased nekton density in ponds
[30]. We hypothesized that freshwater emergent marsh had lower nekton density and biomass to that of freshwater marsh ponds, but our results indicate that they did not statistically differ. High variability in nekton density within the freshwater emergent marsh and ponds suggests that nekton in freshwater emergent marsh are patchily distributed. Despite the high variability and limited temporal availability, the freshwater emergent marsh is still an important and widely distributed habitat for nekton.

Individual species responses to habitat attributes (e.g., vegetation cover) may be predicted in the context of their life history-environment relationships [31]. Our results indicated that common pond inhabitants (i.e., mosquitofish, least killifish) were common in the freshwater emergent marsh. This finding is similar to previous studies that found relatively higher population densities of mosquitofish and least killifish in shallow water with thick vegetation, low DO and salinity [19,32,33]. Some abundant species in freshwater ponds, however, were not caught in freshwater emergent marsh as expected. We expected banded pygmy sunfish and golden topminnow to have relatively higher density in freshwater emergent marsh because they prefer shallow water with macrophytes [34-35]. [36] noted vegetation structural complexity may affect nekton habitat use in SAV (e.g., pond) and the freshwater emergent marsh. Differences in the structural complexity of vegetation between habitat types may have been responsible for the absence of banded pygmy sunfish and the relatively low density of golden topminnow. These findings suggest that some abundant species in freshwater emergent marsh and ponds may be well adapted to low DO with high vegetation cover.

Dry conditions are common in wetlands and are an important part of the hydrological cycle. Variation in life history traits of nekton seems to be correlated with hydrologic condition (i.e., flooding duration). [37] noted that flow regime adaptations range from behaviors that result in the avoidance of individual floods or droughts, to life-history strategies that are synchronized with longterm flow patterns. In addition, [13] noted that many fish species in highly variable flow regimes have evolved life history strategies that ensure strong recruitment. Our results of high variability in nekton density within the freshwater emergent marsh indicate that nekton is patchily distributed. Furthermore, we observed that variability in flooding is common among years during the same season. During spring sampling, the freshwater emergent marsh was flooded, providing ample access to the marsh by nekton. However, during March to May 2010 (spring period), dry conditions prevailed and the marsh remained unflooded (unpublished data, no nekton sample). Strictly from a nekton perspective, our results suggest that anthropogenic activities such as marsh management that 
increases or decreases duration of lateral hydrologic connection between freshwater emergent marsh and adjacent water bodies can potentially alter nekton habitat value (i.e., non-suitable, less suitable, suitable) in freshwater marsh.

Previous studies $[38,39]$ noted that the natural flow regime has a profound influence on the biodiversity of aquatic ecosystems (e.g., streams, rivers and their floodplain wetlands). Several interrelated flow characteristics influence nekton assemblages in aquatic systems at different temporal and spatial scales; no single flow characteristic is responsible. [13] noted that it is difficult to resolve which attributes of the altered flow regime are directly responsible for observed impacts. Similarly, in our study, it is unclear as to what hydrologic characteristics are most important in structuring nekton communities in freshwater marsh. Additional long-term research on the effects of flow regime in the freshwater marsh on nekton assemblages would potentially improve our understanding of nekton habitat requirements.

\section{ACKNOWLEDGEMENTS}

This project was supported by a Louisiana Department of Wildlife and Fisheries and U.S. Fish and Wildlife Service State Wildlife Grant with support also from the International Crane Foundation. We thank M. La Peyre, J. A. Nyman, R. Keim, A. Rutherford, and S. Piazza for their critical insights. The authors would like to acknowledge the field and laboratory contributions of J. Linscombe, R. Cormier, M. Huber, and A. Williamson. In addition, we extend gratitude to M. Kaller for statistical assistance. We appreciate the comments of two anonymous reviewers, whose suggestions improved this manuscript. Collections were made under Louisiana State University AgCenter Animal Care and Use protocol (\#AE2008-012). Any use of trade, firm, or product names is for descriptive purposes only and does not imply endorsement by the U.S. Government.

\section{REFERENCES}

[1] Remmert, H. (1983) Studies and thoughts about the zonation along the rocky shores of the Baltic. Zoologica, 22, 121-125.

[2] Martino, E.J. and Able, K.W. (2003) Fish assemblages across the marine to low salinity transition zone of a temperate estuary. Estuarine, Coastal and Shelf Science, 56, 969-987. doi:10.1016/S0272-7714(02)00305-0

[3] Whoriskey, F.G. and Fitzgerald, G.J. (1989) Breedingseason habitat use by sticklebacks (Pisces: Gasterosteidae) at Isle Verte, Quebec. Canadian Journal of Zoology, 67, 2126-2130. doi:10.1139/z89-302

[4] Szedlmayer, S.T. and Able, K.W. (1993) Ultrasonic telemetry of age- 0 summer flounder, Paralichthys dentatus, movements in a southern New Jersey estuary. Copeia, 1993, 728-736. doi: $10.2307 / 1447234$

[5] Lake, P.S. (2003) Ecological effects of perturbation by drought in flowing waters. Freshwater Biology, 46, 11611172. doi:10.1046/j.1365-2427.2003.01086.x

[6] Humphries, P. and Baldwin, D.S. (2003) Drought and aquatic ecosystem: An introduction. Freshwater Biology, 48, 1141-1146. doi:10.1046/j.1365-2427.2003.01092.x

[7] Minello, T.J., Rozas, L.P. and Baker, R. (2012) Geographic variability in salt marsh flooding patterns may affect nursery value for fishery species. Estuaries and Coasts, 35, 501-514. doi:10.1007/s12237-011-9463-x

[8] Welcomme, R.L. (1985) River fisheries. Food and Agriculture Organization of the United Nations, FAO Fisheries Technical Paper 262.

[9] Junk, W.J., Bayley, P.B. and Sparks, R.E. (1989) The flood-pulse concept in river-floodplain systems. In: Dodge, D.P., Ed., Proceedings of the International Large River Symposium (LARS), Canadian Journal of Fisheries and Aquatic Sciences Special Publication 106, NRC research press, Ottawa, 110-127.

[10] Copp, G.H. (1990) Effect of regulation on 0+ fish recruitment in the Great Ouse, a lowland river. Regulated Rivers: Research and Management, 5, 251-163. doi:10.1002/rrr.3450050306

[11] Sparks, R.E. (1995) Need for ecosystem management of large rivers and floodplains. BioScience, 45, 168-182. doi: $10.2307 / 1312556$

[12] Humphries, P., King, A.J. and Koehn, J.D. (1999) Fish, flows and floodplains: Links between freshwater fishes and their environment in the Murray-Darling River system, Australia. Environmental Biology of Fishes, 56, 129151. doi:10.1023/A:1007536009916

[13] Bunn, S.E. and Arthington, A.H. (2002) Basic principles and ecological consequences of altered flow regimes for aquatic biodiversity. Environmental Management, 30, 492-507. doi:10.1007/s00267-002-2737-0

[14] Rozas, L.P. and Minello, T.J. (1999) Effects of structural marsh management on fishery species and other nekton before and during a spring drawdown. Wetlands Ecology and Management, 7, 121-139. doi:10.1023/A:1008434727703

[15] Dunson, W.A., Friacano, P. and Sadinski, W.J. (1993) Variation in tolerance to abiotic stresses among sympatric salt marsh fish. Wetlands, 13, 16-24. doi:10.1007/BF03160861

[16] Rowe, C.L. and Dunson, W.A. (1995) Individual and interactive effects of salinity and initial fish density on a salt marsh assemblage. Marine Ecology Progress Series, 128, 271-278. doi:10.3354/meps 128271

[17] Gascon, S., Boix, D., Sala, J. and Quintana, X.D. (2008) Relation between macroinvertebrate life strategies and habitat traits in Mediterranean salt marsh ponds (Emporda wetlands, NE Iberian Peninsula). Hydrobiologia, 597, 71-83. doi:10.1007/s10750-007-9215-x

[18] McKinsey, D.M. and Chapman, L.J. (1998) Dissolved oxygen and fish distribution in a Florida spring. Environmental Biology of Fishes, 53, 211-223. doi:10.1023/A:1007497503542

[19] Hubbs, C. (1971) Competition and isolation mechanisms in the Gambusia affinis X G. heterochir hydrid swarm. 
Texas Memorial Museum Bulletin, 19, 1-46.

[20] Cattrijsse, A., Makwaia, E.S., Dankwa, H.R., Hamerlynck, O. and Hemminga, M.A. (1994) Nekton communities of an intertidal creek of a European estuarine brackish marsh. Marine Ecology Progress Series, 109, 195-208. doi:10.3354/meps 109195

[21] Hampel, H. (2003) Factors influencing the habitat value of tidal marshes for nekton in the Westerschelde estuary. Ph.D. Dissertation, University of Gent, Belgium.

[22] Cattrijsse, A. and Hampel, H. (2006) European intertidal marshes: A review of their habitat functioning and value for aquatic organisms. Marine Ecology Progress Series, 324, 293-307. doi:10.3354/meps324293

[23] La Peyre, M.K., Gossman, B. and Nyman, J.A. (2007) Assessing functional equivalency of nekton habitat in enhanced habitats: Comparison of terraced and unterraced marsh ponds. Estuaries and Coasts, 30, 526-536. doi:10.1007/BF03036518

[24] Kang, S.R. and King, S.L. (2013) Effects of hydrologic connectivity and environmental variables on nekton assemblage in a coastal marsh system. Wetlands, 33, 321334 doi:10.1007/s13157-013-0386-0

[25] Chabreck, R.H. and Nyman, J.A. (2005) Management of coastal wetlands. In: Braun, C.E., Ed., Techniques for Wildlife Investigations and Management, The Wildlife Society, Bethesda, 839-860.

[26] Visser, J.M., Sasser, C.E., Chabreck, R.H. and Linscombe, R.G. (1998) Marsh vegetation types of the Mississippi river deltaic plain. Estuaries, 21, 818-828. doi: $10.2307 / 1353283$

[27] Rozas, L.P. and Minello, T.J. (2010) Nekton density patterns in tidal ponds and adjacent wetlands related to pond size and salinity. Estuaries and Coasts, 33, 652-667. doi:10.1007/s12237-009-9258-5

[28] Kushlan, J.A. (1981) Sampling characteristics of enclosure fish traps. Transactions of the American Fisheries Society, 110, 557-562. doi:10.1577/1548-8659(1981)110<557:SCOEFT $>2.0 . \mathrm{CO}$ :2

[29] Fernandes, R., Gomes, L.C., Pelicice, F.M. and Agostinho, A.A. (2009) Temporal organization of fish assemblages in floodplain lagoons: The role of hydrological connectivity.
Environmental Biology of Fishes, 85, 99-108. doi:10.1007/s10641-009-9466-7

[30] Minello, T.J. (1999) Nekton densities in shallow estuarine habitats of Texas and Louisiana and the identification of essential fish habitat. American Fisheries Society Symposium, 22, 43-75.

[31] Olden, J.D., Poff, N.L. and Bestgen, K.R. (2006) Lifehistory strategies predict fish invasions and extirpations in the Colorado River basin. Ecological Monographs, 76, 25-40. doi:10.1890/05-0330

[32] Douglas, N.H. (1974) Freshwater fishes of Louisiana. Claitor's Publishing Division, Baton Rouge.

[33] Chervinski, J. (1983) Salinity tolerance of the mosquitofish, Gambusia affinis (Baird and Girard). Journal of Fish Biology, 22, 9-11. doi:10.1111/j.1095-8649.1983.tb04720.x

[34] Shute, J.R. (1980) Fundulus chrystotus, Golden topminnow. In: Lee, D.S., Gilbert, C.R., Hocutt, C.H., Jenkins, R.E., McAllister, D.E. and Stauffer J.R. Atlas of North American Freshwater Fishes, North Carolina Museum of Natural Sciences Publication, Raleigh, 510.

[35] Moriarty, L.J. and Winemiller, K.O. (1997). Spatial and temporal variation in fish assemblage structure in Willage Creek, Hardin County Texas. Texas Journal of Science, 49, 85-110.

[36] Castellanos, D.L. and Rozas, L.P. (2001) Nekton use of submerged aquatic vegetation, marsh, and shallow unvegetated bottom in the Atchafalaya River delta, a Louisiana tidal freshwater ecosystem. Estuaries, 24, 184-197. doi: $10.2307 / 1352943$

[37] Lytle, D.A. and Poff, N.L. (2004) Adaptation to natural flow regimes. Trends in Ecology and Evolution, 19, 94100. doi:10.1016/i.tree.2003.10.002

[38] Poff, N.L., Allan, J.D., Bain, M.B., Karr, J.R., Prestegaard, K.L., Richter, B.D., Sparks, R.E. and Stromberg, J.C. (1997) The natural flow regime. BioScience, 47, 769-784. doi: $10.2307 / 1313099$

[39] Hart, D.D. and Finelli, C.M. (1999) Physical-biological coupling in streams: The pervasive effects of flow on benthic organisms. Annual Review of Ecology and Systematics, 30, 363-395. doi:10.1146/annurev.ecolsys.30.1.363 